\title{
FAKTOR-FAKTOR YANG MEMPENGARUHI DIVIDEND PAYOUT RATIO PADA PERUSAHAAN NON KEUANGAN
}

\author{
ISABELLA dan APIT SUSANTI \\ STIE Trisakti \\ apitsusanti@yahoo.com \\ Isabellalunggana@gmail.com
}

\begin{abstract}
The purpose of this study was to examine if profitability,operating cash flow per share, corporate tax, current ratio, market to book value, debt to equity ratio, firm size, and life cycle stage in affecting dividend payout ratio in non financial companies liested in Indonesia stock exchange. This research used 110 listed non financial companies in Indonesia Stock Exchange, selected using purposive sampling method in period 2012 to 2014. The data were analyzed using multiple regressions analysis method to determine the model of research. The result of the analysis indicated that profitability, operating cash flow per share, corporate tax, market to book value, debt to equity ratio,firm sizeandlife cycle stagehad influence on dividend payout ratio. But current ratio had no influence on dividend payout ratio.
\end{abstract}

Keywords: dividend payout ratio, profitability, operating cash flow, corporate tax, market to book value, debt to equity ratio, firm size, current ratio, life cycle stage

\begin{abstract}
Abstrak: Tujuan penelitian ini adalah untuk menguji apakah profitabilitas, operating cash flow per share, corporate tax, current ratio, market to book value, debt to equity ratio, ukuran perusahaan, dan life cycle stage memiliki pengaruh terhadap dividend payout ratio di perusahaan non keuangan yang terdaftar di Bursa Efek Indonesia. Penelitian ini menggunakan 110 perusahaan non keuangan yang terdaftar di Bursa Efek Indonesia, dipilih menggunakan metode purposive sampling dalam periode 2012 sampai 2014. Data penelitian ini dianalisis menggunakan metode analisis regresi berganda dalam model penelitian. Hasil dari penelitian ini menunjukkan bahwa profitabilitas, operating cash flow per share, corporate tax, market to book value, debt to equity ratio, ukuran perusahaan dan life cycle stage berpengaruh terhadap dividend payout ratio. Sedangkan current ratio tidak berpengaruh terhadap dividend payout ratio
\end{abstract}

Kata kunci: dividend payout ratio, profitabilitas, operating cash flow, corporate tax, market to book value, debt to equity ratio, ukuran perusahaan, current ratio, life cycle stage 


\section{PENDAHULUAN}

Perkembangan bisnis dalam era globalisasi mengakibatkan persaingan yang semakin ketat antar perusahaan. Hal ini yang menyebabkan perusahaan harus meningkatkan kinerja perusahaannya dengan cara perusahaan bekerja lebih sinergis dalam mengelola bisnisnya untuk mencapai tujuan. Agar tetap sinergis perusahaan juga diperlukan untuk dapat mengelola sumber pendanaan yang baik agar dapat digunakan secara optimal dan dapat memuaskan investor karena tingkat pengembalian yang menguntungkan.

Manajer suatu perusahaan harus memperhatikan sumber pembiayaan yang akan digunakan perusahaan baik sumber internal atau sumber external yang akan memberikan pengaruh bagi dividend payout ratio. Apabila sumber dana yang digunakan berasal dari sumber dana eksternal perusahaan yang berasal dari hutang maka hal ini akan mengakibatkan resiko perusahaan semakin tinggi dan untuk investor akan menimbulkan persepsi negatif. Sedangkan sumberdana internal adalah berasal dari hutang dan modal yaitu berupa saham.

Dividen adalah pembagian keuntungan yang diperoleh perusahaan kepada para pemegang saham yang dilakukan secara periodik. Dividen merupakan bagian dari laba bersih yang akan dibagikan kepada para pemegang saham yang akan dibandingkan dengan lembar jumlah saham yang dimiliki. Sehingga ini dapat menentukan bahwa hanya perusahaan yang menghasilkan keuntungan yang dapat membagikan dividen dikarenakan dividen yang dibagikan adalah dividen yang berasal dari keuntungan yang didapatkan perusahaan (Gitmandan Zutter 2015).

Manajer perusahaan memiliki peran yang sangat penting terutama dalam proses pengambilan keputusan dalam menentukan pembayaran dividen bagi suatu perusahaan, Seorangmanajer perusahaan dalam rutinitasnya sering dihadapkan pada berbagai keputusan yang sangat penting dan hal ini berkenaan dengan keuangan yang ada di dalam perusahaan tersebut. Salah satu keputusan penting yang harus diambil oleh seorang manajer perusahaan adalah pengambilan keputusan mengenai kebijakan pembayaran dividen yang harus ditetapkan perusahaan tersebut.

Menurut Gitmandan Zutter (2015) menyatakan bahwa, Dividend Policy adalah keputusan apakah perusahaan akan membagikan keuntungan yang diperolehnya kepada para pemegang saham sebagai dividen atau keuntungan yang diperoleh dalam bentuk laba yang ditahan. Perusahaan harus bijaksana dalam memutuskan kebijakan dividen dikarenakan hal ini akan memberikan pengaruh dalam pengambilan keputusan untuk menentukan besarnya laba yang ditahan dan pembagian dividen untuk perusahaan.

Menentukan kebijakan dividen bagi perusahaan harus didasarkan pada beberapa pertimbangan dari pihak manajemen perusahaan dengan melihat berbagai faktor yang akan memberikan dampak bagi perusahaan maupun bagi investor. Faktor-faktor yang dapat mempengaruhi kebijakan dividen adalah tarif pajak yang akan dikenakan untuk dividen, peluang investasi perusahaan, biaya ketersediaan sumber modal alternatif atau sumber modal cadangan dan preferensi para pemegang saham atas pendapatan saat ini dibandingkan dengan pendapatan yang akan diterima perusahaan untuk masa yang akan datang (Weston dan Brigham 1986 ).

\section{Life Cycle Theory}

Menurut DeAngelo et al. (2006), Teori ini menyatakan bahwa keputusan dividen akan dipengaruhi oleh kebutuhan perusahaan dalam mendistribusikan aliran kasnya. Teori ini memprediksikan bahwa pada tahun awal sejak pendirian, hanya sedikit perusahaan yang akan membayar dividen, tetapi apabila dividen yang 
dibayarkan oleh perusahaan mengalami peningkatan, maka hal ini akan menunjukkan tingkat kedewasaan atau kemapanansuatu perusahaan yaitu apabila dana internal yang dimiliki oleh perusahaan telah mencapai dan melewati peluang agar perusahaan dapat melakukan investasi.

Perusahaan yang sedang berada dalam tahap pertumbuhan lebih cenderung untuk tidak ingin membayarkan dividen dikarenakan perusahaan tersebutmemiliki tingkat kuantitatif keuntungan yang besar untuk melakukan investasi namun perusahaan memiliki tingkat pendanaan yang terbatas. Sehingga laba yang didapatkan akan ditahan sebagai retained earnings atau laba ditahan dan dapat di investasikan kembali karena apabila menggunakan pendanaan yang berasal dari dalam perusahaan atau pendanaan internal maka hal tersebut akan menghemat biaya atau biaya yang dikeluarkan akan lebih murah dibandingkan dengan menggunakan pendanaan yang berasal dari luar perusahaan atau pendanaan eksternal (DeAngelo et al. 2006).

\section{Signaling Theory}

Signaling theory merupakan hal yang penting bagi pihak investor dimana melalui hipotesis ini para investor dapat menangkap informasi melalui sinyal-sinyal yang berasal dari pengumuman dividen yang akan memberikan informasi mengenai perubahan dividen maupun tingkat kestabilan perusahaan untuk mengetahui informasi laba dimasa mendatang. Namun agar hipotesis sinyal dapat dijalankan maka manajer harus mampu mendorong informasi tersebut agar informasi dapat sampai ke pasar (Refra dan Widiastuti 2014).

Modigliani dan Miller berpendapat bahwa manajemen perusahaan biasanya melihat perubahan yang terjadi pada dividen untuk meramalkan penghasilan yang akan diperoleh perusahaan dimasa yang akan datang. Apabila terjadi kenaikan dividen maka hal ini merupakan sinyal kepada para pemegang saham dimana perusahaan akan memiliki penghasilan yang baik dimasa mendatang dan apabila terjadi penurunan dividen atau kenaikan dividen dibawah normal maka hal ini diyakini oleh para pemegang sahamadalah sebagai sinyal dimana perusahaan akan menghadapi kesulitan dimasa yang akan datang (Sjahrial 2010).

\section{Clientle Effect Theory}

Menurut Refra dan Widiastuti (2014), didalam teori ini terdapat dua kelompok para pemegang saham yaitu kelompok yang pertama adalah kelompok dengan pemegang saham yang menyukai dividen hal ini berarti pemegang saham lebih menyukai jika perusahaaan memberikan tingkat dividend payout ratio yang tinggi, kelompok yang kedua lebih menyukai dengan menerima capital gain hal ini berarti para pemegang saham lebih menyukai apabila perusahaan menahan sebagian dari laba bersih. Pada teori ini seharusnya perusahan lebih fokus dikarenakan perusahaan akan menghadapi beragam karakteristik pemegang saham sehingga mampu meminimalisir kekecewaan.

Perbedaan pajak yang dihasilkan dari masing-masing individu dapat menimbulkan adanya penundaan pembayaran terhadap pajak misalnya seperti orang yang sudah lanjut usia maka akan dikenakan pajak yang lebih ringan dibandingkan kelompok yang lain. Kelompok seperti ini akan lebih menyukai apabila perusahaan membagikan dividen yang kecil. Dengan demikian maka kelompok dengan pemegang saham yang dikenakan pajak tinggi maka lebih menyukai capital gain dan hal ini berlaku sebaliknya (Sjahrial 2010). 


\section{Dividend Payout Ratio}

Dividen merupakan pembagian keuntungan atau laba yang diperoleh perusahaan yang akan diberikan kepada para pemegang saham perusahaan. Dimana dividen tersebut adalah termasuk dalam laba bersih yang akan dibagikan kepada para pemegang saham yang akan dibandingkan dengan jumlah lembar saham yang dimiliki. Namun hanya perusahaan yang mendapatkan keuntungan yang berhak untuk membagikan dividen, hal ini dikarenakan dividen yang diambil adalah dividen yang berasal dari keuntungan perusahaan (Sjahrial 2010).

Menurut Sjahrial (2010) terdapat beberapa faktor-faktor yang dapat mempengaruhi besarnya dividend payout ratio yaitu:

1. Faktor likuiditas yaitu semakin tinggi likuiditas akan meningkatkan dividen yang dibayarkan dan sebaliknya semakin rendah likuiditas maka akan menurunkan tingkat dividen yang dibayarkan.

2. Kebutuhan dana untuk melunasi hutang, semakin besar dana untuk melunasi hutang maka akan berakibat menurunkan pembayaran dividendan sebaliknya.

3. Perluasan usaha yaitu apabila perluasan usaha perusahaan semakin besar maka dana yang akan dibayarkan untuk dividen akan berkurang.

4. Faktor pengawasan terhadap perusahaan yaitu semakin terbukanya perusahaan maka akan memperkuat modal sendiri sehingga mengakibatkan kenaikan dividendan sebaliknya semakin tertutupnya perusahaan akan menurunkan dividen.

\section{Profitabilitas}

Menurut Siswantini (2014), mengemukakan bahwa profitabilitas adalah kemampuan perusahaan untuk dapat menghasilkan keuntungan setelah melewati berbagai keputusan dan kebijakan manajemen. Didalam hal ini analisis rasio yang dilakukan adalah untuk mengukur tingkat pendapatan menurut laporan rugi laba dengan nilai buku investasi. Profitabilitas berpengaruh terhadap dividen dikarenakan dividen merupakan bagian dari laba bersih yang didapatkan oleh perusahaan. Perusahaan yang memperoleh laba maka akan membagikan dividen kepada pemegang saham dan besarnya pembayaran dividen ditentukan oleh besarnya tingkat profitabilitas perusahaan (Refra dan Widiastuti 2014).

Menurut Bansaleng et.al (2014),Investor yang telah melakukan pengamatan terhadap tingkat profitabilitas menunjukkan bahwa suatu perusahaan yang memiliki investasi dengan tingkat keuntungan yang tinggi maka perusahaan tersebut menggunakan pendanaan yang berasal dari pendanaan internal atau dana yang dihasilkan oleh perusahaan yang berasal dari keuntungan yang dihasillkan sendiri. Hal ini menunjukkan bahwa profitabilitas memiliki hubungan antara pendapatan dan biaya dimana keduanya saling berkaitan dengan menggunakan aktiva perusahaan yaitu aktiva lancar maupun aktiva tetap (Gitman dan Zutter 2015).

\section{Operating cash flow per share}

Menurut Kristanto dan Sumani (2015), Laporan dalam arus kas terdiri dari tiga bagian yaitu aktivitas operasi, aktivitas investasi, dan aktivitas pendanaan. Pengklasifikasian dalam laporan arus kas bermanfaat untuk memberikan informasi kepada pengguna mengenai penilaian dampak yang dihasilkan dari setiap aktivitas terhadap posisi keuangan entitas. Pengertian arus kas operasi merupakan aliran kas yang diterima atau dikeluarkan oleh perusahaan akibat dari kegiatan yang dilakukan oleh perusahaan selain yang berasal dari operasi yaitu investasi dan pendanaan.

Arus masuk kas operasi berasal dari pengumpulan kas dari langganan, penerimaan bunga atas pinjaman dan penerimaan dividen atas investasi saham, sedangkan arus keluar operasi berasal dari pembayaran bunga dan 
pajak, serta pembayaran terhadap karyawan dan pemasok. Arus kas yang positif merupakan hal yang baik untuk perusahaan dikarenakan apabila terjadi peningkatan pada arus kas perusahaan maka akan memberikan pengaruh yang signifikan untuk dividen (Dhira et al. 2014).

Perusahaan yang memiliki arus kas yang tinggi maka perusahaan tersebut akan menghasilkan pembayaran dividen yang tinggi dan jika perusahan memiliki arus kas yang rendah maka pembayaran terhadap dividen akan menurun dan hal ini menjadi pertanda buruk bagi perusahaan dimasa mendatang yang akan menunjukkan bahwa perusahaan tersebut kemungkinan besar akan mengalami kesulitan (Utami dan Robin 2015).

\section{Corporate Tax}

Pengertian pajak bedasarkan UU No. 28 tahun 2007 pasal 1 (satu) adalah kontribusi wajib kepada negara yang terutang oleh orang pribadi atau badan yang bersifat memaksa berdasarkan undang-undang, dengan tidak mendapatkan imbalan secara langsung dan digunakan untuk keperluan negara bagi sebesar-besarnya kemakmuran rakyat. Perubahan peraturan perpajakan dalam setiap periode akan memberikan pengaruh bagi kebijakan dividen yang akan dibagikan oleh perusahaan.

Pajak perusahaan merupakan salah satu variabel yang dapat memberikan pengaruh yang buruk atau negatif terhadap pembayaran dividen perusahaan. Hal ini dapat dijelaskan dengan fakta bahwa jumlah pajak yang akan dibayarkan oleh perusahaan dapat mengurangi jumlah pendapatan perusahaan dan dapat menyebabkan penurunan proporsi pendapatan perusahaan tersebut untuk dapat dibagikan sebagai bentuk dari pembayaran dividen kepada para pemegang saham (Demirgunes Kartal 2015).

\section{Current Ratio}

Current ratio merupakan bagian dari rasio likuiditas yang biasanya digunakan untuk menunjukkan kemampuan suatu perusahaan dalam memenuhi kewajiban jangka pendeknya (Gitman dan Zutter 2015). Apabila aktiva dikonversikan dengan cepat ke dalam kas maka kemungkinan aktiva tersebut relatif likuid. Oleh sebab itu maka likuid atau tidak likuidnya suatu aktiva akan ditentukan oleh seberapa cepat aktiva dapat dikonversikan ke dalam kas. Setiap rasio likuiditas akan mencerminkan perspektif waktu yang berbeda dalam melakukan pengukuran untuk melihat kemampuan perusahaan dalam memenuhi kewajiban jangka pendeknya (Tampubolon 2005).

Current ratio akan memberikan gambaran untuk para investor dikarenakan dari perhitungan tersebut akan menunjukkan kondisi suatu perusahaan. Kondisi seperti ini dapat terlihat apabila current ratio suatu perusahaan semakin tinggi, maka hal ini menunjukkan bahwa perusahaan mampu untuk membayar hutang atau kewajiban jangka pendeknya terutama dalam membayar dividen yang terhutang dan akan mempengaruhi investor untuk mengurangi rasa ketidakpastian terhadap dividen yang diharapkan dan apabila current ratio semakin rendah, hal ini berarti bahwa perusahaan tidak dapat memenuhi kewajiban jangka pendeknya (Samrotun 2015).

\section{Market to Book Value}

Menurut Gitman dan Zutter (2015), menyatakan bahwa market to book value merupakan rasio yang memberikan penilaian mengenai bagaimana cara investor melihat kinerja perusahaan, hal ini berkaitan dengan nilai pasar saham perusahaan terhadap nilai buku. Teori pecking order memprediksi bahwa perusahaan dengan ukuran yang besar dari nilai 
pasarnya yang dinilai berdasarkan peluang untuk bertumbuh sebaiknya menambah pendapatan ditahan sehingga perusahaan dapat mengurangi kebutuhan akan penambahan modal (Myers dan Majluf 1984).

Rasio market to book value ini digunakan untuk mengetahui seberapa besar harga saham yang ada di pasar dibandingkan nilai buku sahamnya.Rasio ini menjadi tolak ukur untuk menentukan seberapa jauh perusahaan memilih investment opportunities. Investment opportunities merupakan suatu peluang yang dimiliki perusahaan dimana perusahaan akan memperoleh suatu keuntungan. Investment opportunities dapat berjalan apabila perusahaan memiliki dana yang cukup. Hambatan yang sering dihadapi oleh manajemen perusahaan adalah ketika memutuskan apakah perusahaan akan membagikan dividen atau mendistribusikan dana untuk melakukan investasi (Fama dan French 2001) .

\section{Debt to Equity Ratio}

Debt to equity ratio termasuk salah satu bagian dari rasio leverage. Debt to equity ratio merupakan hasil dari penggunaan biaya tetap atau dana yang digunakan untuk memperbesar tingkat pengembalian kepada pemilik perusahaan. Rasio leverage memiliki tingkat resiko yang tinggi dikarenakan adanya pengembalian yang harus dilunasi. Debt to equity ratio juga digunakan untuk mengetahui seberapa besar modal yang dimiliki perusahaan yang dijadikan jaminan atas hutang perusahaan (Gitman dan Zutter 2015).

Beban perusahaan akan bertambah apabila perusahaan menggunakan modal yang berasal dari pinjaman. Hal ini dikarenakan adanya beban bunga yang timbul akibat pinjaman tersebut. Perusahaan yang menggunakan modal sendiri dan yang bukan berasal dari pinjaman maka perusahaan diharuskan untuk membagikan dividen sebagai proses balas jasa yang diberikan perusahaan kepada pemegang saham. Jadi, semakin besar perusahaan menggunakan modal yang berasal dari pemegang saham maka akan semakin besar pula dividen yang dibagikan (Suprihati 2015).

\section{Ukuran Perusahaan}

Menurut Refra dan Widiastuti (2014), ukuran perusahaan merupakan suatu gambaran untuk menentukan total aktiva perusahaan. Ukuran perusahaan menjadi salah satu faktor untuk pengambilan keputusan mengenai kebijakan dalam pembagian dividen kepada investor. Sedangkan bagi investor ukuran perusahaan adalah hal yang sangat penting dikarenakan dengan melihat ukuran perusahaan investor dapat memutuskan apakah investor ingin melakukan investasi dengan perusahaan tersebut atau tidak berinvestasi dan ukuran perusahaan akan menjadi daya tarik bagi pihak investor (Mahesti dan Mujilan 2013).

Perusahaan besar memiliki akses yang lebih baik untuk kepasar modal dan memiliki hambatan yang lebih sedikit dibandingkan dengan perusahaan kecil, hal ini menunjukkan bahwa meningkatnya ukuran perusahaan dapat menurunkan ketergantungan perusahaan terhadap penggunaan dana internal Perusahaan yang memiliki tingkat aset yang tinggi akan menunjukkan bahwa perusahaan tersebut telah mencapai tahap mapan sehingga memiliki prospek pembagian dividen yang baik di masa mendatang (Thanatawee 2011).

\section{Life Cycle Stage}

Life cycle stage menggambarkan perusahaan yang sedang berada dalam tahap dewasa akan memiliki tingkat keuntungan lebih besar. Life cycle stage akan memberikan pengaruh pada kebijakan dividen yang optimal. Life cycle theory berpendapat bahwa kebijakan dividen yang optimal bergantung pada stadium life cycle stage. Perusahaan yang berada pada tahap pertumbuhan yang tinggi maka akan menggunakan sumber eksternal untuk membiayai investasi dikarenakan pendapatan mereka rendah. oleh sebab itu apabila suatu 
perusahaan sudah berada dalam tahap yang mapan maka rasio ini akan meningkat (Refra dan Widiastuti 2014).

Perusahaan memutuskan untuk tidak akan membagikan dividen apabila perusahaan tersebut sedang berada dalam tahap pertumbuhan, hal ini dikarenakan perusahaan akan lebih memilih untuk menahan keuntungan dan membiayai aktivitas perusahaan. Hal tersebut dapat menentukan bahwa life cycle stage perusahaan akan berpengaruh negatif terhadap kebijakan dividen apabila perusahaan sedang berada dalam fase pertumbuhan, sedangkan apabila suatu perusahaan sedang dalam tahap dewasa maka life cycle stage akan berpengaruh positif terhadap kebijakan dividen (Refra dan Widiastuti 2014).

\section{Model Penelitian}

Model penelitian yang menghubungkan antara variabel independen terhadap variabel dependen, adalah sebagai berikut:

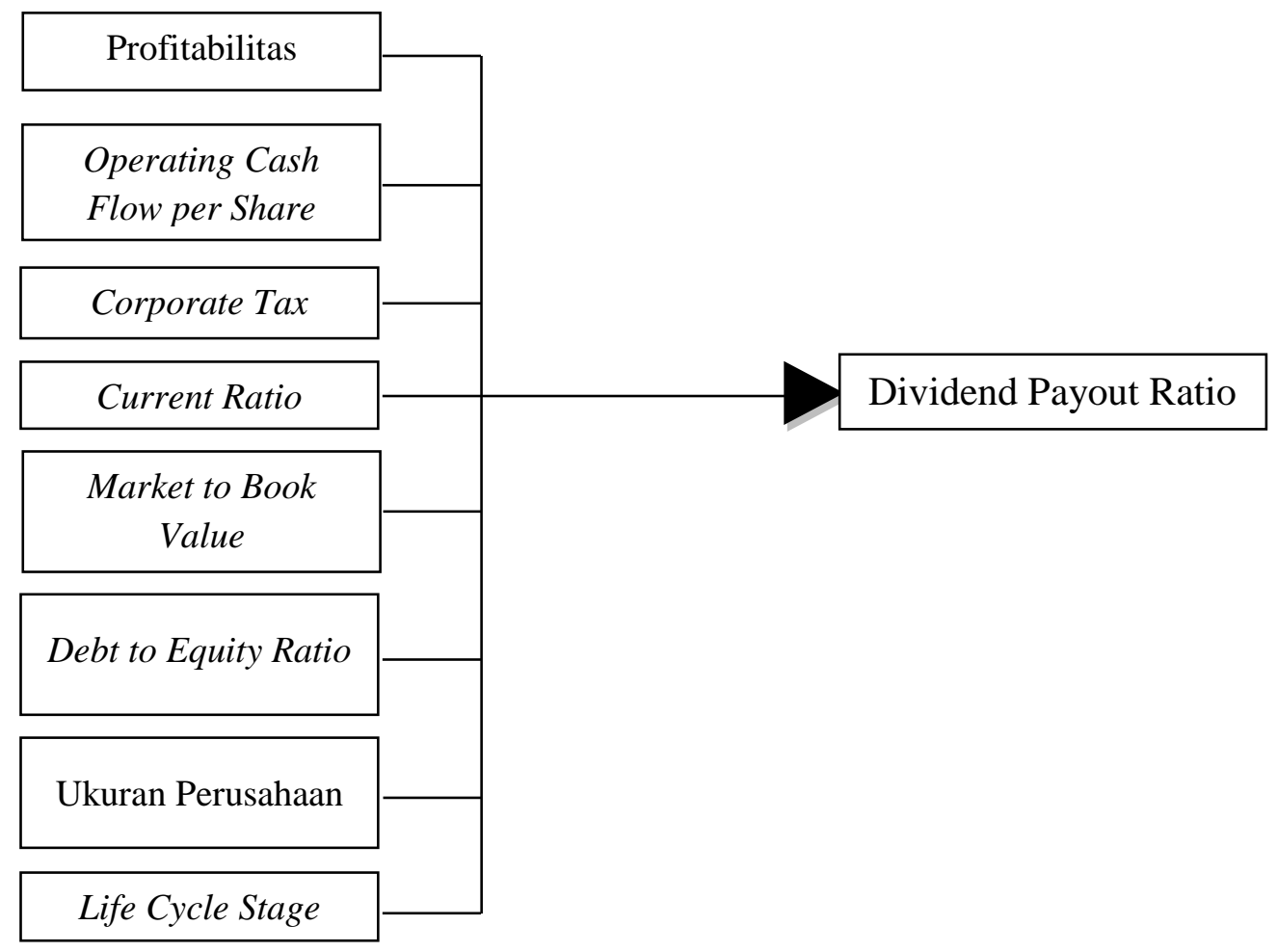

Gambar 1 Model Penelitian 


\section{Pengembangan Hipotesis}

Berdasarkan model penelitian yang ada maka hipotesis yang diajukan untuk penelitian ini adalah:

$\mathrm{H}_{1}$ : Profitabilitas memiliki pengaruh terhadap dividend payout ratio perusahaan.

$\mathrm{H}_{2}$ : Operating cash flow per share memiliki pengaruh terhadap dividend payout ratio perusahaan.

$\mathrm{H}_{3}$ : Corporate tax memiliki pengaruh terhadap dividend payout ratio perusahaan.

$\mathrm{H}_{4}$ : Current ratio memiliki pengaruh terhadap dividend payout ratio perusahaan.

$\mathrm{H}_{5}$ : Market to book value memiliki pengaruh terhadap dividend payout ratio perusahaan.
$\mathrm{H}_{6}$ : Debt to equity ratio memiliki pengaruh terhadap dividend payout ratio perusahaan.

$\mathrm{H}_{7}$ : Ukuran perusahaan memiliki pengaruh terhadap dividend payout ratioperusahaan.

$\mathrm{H}_{8}$ : Life cycle stage memiliki pengaruh terhadap dividend payout ratio perusahaan.

\section{METODE PENELITIAN}

Berdasarkan perusahaan non keuangan yang terdaftar di Bursa Efek Indonesia periode 2012 sampai 2014, sampel yang digunakan oleh peneliti sebanyak 110 perusahaan. Sampel perusahaan yang menjadi data penelitian dipilih berdasarkan kriteria-kriteria pemilihan sampel yang telah ditentukan adalah sebagai berikut:

Tabel 1 Proses Pemilihan Sampel

\begin{tabular}{clcc}
\hline No. & Keterangan & Jumlah & Data \\
\hline 1 & $\begin{array}{l}\text { Perusahaan non keuangan yang terdaftar di Bursa Efek } \\
\text { Indonesia tahun 2012 sampai dengan tahun 2014. }\end{array}$ & 388 & 1164 \\
2 & $\begin{array}{l}\text { Perusahaan yang tidak memiliki laporan keuangan yang } \\
\text { berakhir pada 31 Desember setiap tahunnya. }\end{array}$ & (9) & (27) \\
3 & $\begin{array}{l}\text { Perusahaan yang tidak menggunakan mata uang rupiah } \\
\text { dalam laporan keuangannya. }\end{array}$ & $(74)$ & $(222)$ \\
4 & $\begin{array}{l}\text { Perusahaan yang tidak menghasilkan laba dari tahun 2012 } \\
\text { sampai tahun 2014 }\end{array}$ & $(89)$ & $(267)$ \\
5 & $\begin{array}{l}\text { Perusahaan yang tidak membagikan kas dividen secara } \\
\text { berturut-turut dari tahun 2012 sampai tahun 2014. }\end{array}$ & $(106)$ & $(318)$ \\
6 & $\begin{array}{l}\text { Data yang tereliminasi akibat uji outlier adalah } \\
\text { Total perusahaan non keuangan yang digunakan sebagai }\end{array}$ & 110 & 326 \\
& sampel penelitian
\end{tabular}

Sumber: Data diolah

Dividend payout ratio menggunakan skala rasio dan pengukurannya diambil berdasarkan penelitian yang dilakukan Rehman dan Takumi (2012) yaitu dengan membagi yearly dividend dengan net income after tax. Pengukuran variabel ini digambarkan dengan rumus:

$$
\mathrm{DPR}=\frac{\text { Yearly Dividend }}{\text { Net Income After Tax }}
$$

Profitabilitas merupakan rasio yang digunakan untuk mengukur pendapatan dalam laporan laba rugi dengan membandingkan nilai buku investasi. Laba yang dihasilkan oleh perusahaan akan mempengaruhi kemampuan perusahaan untuk mendapatkan pendanaan berupa modal maupun utang (Tampubolon 2005). Skala dari variabel ini adalah skala rasio 
dan pengukurannya mengacu pada penelitian yang Rehman dan Takumi (2012), yaitu dengan membagi earnings before interest and taxes dengan total assets. Variabel profitabilitas ini dapat digambarkan dengan rumus:

$$
\text { PROF }=\frac{\text { Earning Before Interest and Taxes }}{\text { Total Assets }}
$$

Operating Cash flow per share merupakan arus kas operasi yang berasal dari pengumpulan kas langganan, penerimaan bunga atas pinjaman dan penerimaan dividen atas investasi saham, pembayaran bunga dan pajak, serta pembayaran terhadap karyawan dan pemasok (Dhira et al. 2014). Skala dari variabel ini adalah skala rasio dan pengukurannya mengacu pada penelitian Rehman dan Takumi (2012), yaitu menggunakan rasio dari operating cash flow dibagi dengan number of shares out standing yang dapat digambarkan dengan rumus:

$$
\text { CFPS }=\frac{\text { Operating Cash Flow }}{\text { Number of Shares Outstanding }}
$$

Corporate tax merupakan salah satu alat ukur yang digunakan untuk menjelaskan tentang kemampuan perusahaan untuk memenuhi kewajiban pajak (Utami dan Robin 2015). Skala dari variabel ini adalah skala rasio dan pengukurannya mengacu pada penelitian Rehman dan Takumi (2012), yaitu menggunakan rasio dari corporate tax dibagi dengan net profit before tax yang dapat digambarkan dengan rumus:

$$
\mathrm{TAX}=\frac{\text { Corporate Tax }}{\text { Net Profit Before Tax }}
$$

Current ratio merupakan salah satu alat ukur dari rasio likuiditas yang digunakan untuk mengukur apakah perusahaan mampu memenuhi kewajiban jangka pendeknya. Dalam rasio ini dapat terlihat jumlah sebenarnya dari aktiva lancar perusahaan yang akan digunakan untuk menjamin hutang lancarnya (Samrotun 2015). Skala dari variabel ini adalah skala rasio dan pengukurannya mengacu pada penelitian Rehman dan Takumi (2012), yaitu menggunakan rasio dari current asset dibagi dengan current liabilities yang dapat digambarkan dengan rumus:

$$
\mathrm{CR}=\frac{\text { Current Asset }}{\text { Current Liabilities }}
$$

Market to book ratio merupakan rasio yang digunakan untuk memberikan gambaran mengenai penilaian yang akan diberikan para pemegang saham terhadap perusahaan dengan melihat kinerja perusahaan dalam berupaya untuk mengembangkan usahanya (Gitman dan Zutter 2012).

Skala dari variabel ini adalah skala rasio dan pengukurannya mengacu pada penelitian yang dilakukan oleh Rehman dan Takumi (2012), yaitu share price beginning of the year dibagi dengan net asset value per share basic. Menurut Beams et al. (2012) mengemukakan bahwa net asset value merupakan current asset + non current asset - current liabilities - non current liabilities atau sama dengan net asset value = total equity. Oleh sebab itu nilai net asset value pada rumus tersebut akan diambil dari total equity, Rumus dari proksi tersebut adalah sebagai berikut:

$$
\text { MTBV }=\frac{\text { Share Price Beginning of The Year }}{\text { Net Asset Value per Share Basic }}
$$

Samrotun (2015) mendefinisikan Debt to Equity Ratio sebagai salah satu bagian dari rasio leverage yang akan memberikan gambaran mengenai bagaimana suatu perusahaan mampu untuk dapat memenuhi kewajibannya dengan modal yang dimiliki oleh perusahaan tersebut. Variabel ini menggunakan skala rasio dan proksinya diambil dari junal 
penelitian Rehman dan Takumi (2012), yaitu menggunakan rasio dari total liabilities dibagi dengan shareholders equity. Menurut Kieso (2011), menyatakan bahwa IFRS menunjukkan jika equity merupakan persamaan dari shareholders equity, Oleh Sebab itu rumus pada shareholders equity dapat diambil dari total equity, yang dapat digambarkan dengan rumus:

$$
\mathrm{DE}=\frac{\text { Total Liabilities }}{\text { Shareholders Equity }}
$$

Ukuran perusahaan merupakan skala yang digunakan untuk menentukan besar kecilnya suatu perusahaan, yang akan mempengaruhi perusahaaan dalam menentukan bagaimana perusahaan dapat menanggung resiko yang akan dihadapinya dikemudian hari (Samrotun 2015). Skala dari variabel ini adalah skala rasio dan pengukurannya mengacu pada penelitian yang dilakukan Refra dan Widiastuti (2014), yaitu natural log dari total assets. Rumus dari proksi tersebut adalah sebagai berikut:

\section{Firm Size $=\ln$ (Total Asset)}

Life Cycle Stage menunjukkan bahwa suatu perusahaan yang berada dalam tahap dewasa akan memiliki akumulasi keuntungan yang lebih dan perusahaan membayar keuntungan yang tinggi (Refra dan Widiastuti 2014). Variabel ini menggunakan skala rasio dan diproksikan berdasarkan penelitian Refra dan Widiastuti (2014), yaitu retained earnings dibagi dengan total shareholders equity, Menurut Kieso et al. (2011), menyatakan bahwalFRS menunjukkan jika equity merupakan persamaan dari shareholders equity, Oleh Sebab itu rumus pada total shareholders equity dapat diambil dari total equity, yang dapat digambarkan dengan rumus:

$$
\text { Life Cycle Stage }=\frac{\text { Retained Earnings }}{\text { Total Shareholders Equity }}
$$

Penelitian ini dianalisis menggunakan regresi linear berganda dengan significant level atau alpha sebesar 5\%. Pengolahan data dalam penelitian ini menggunakan software IBM SPSS Statistics 19. Model hubungan variabel akan dianalisis sesuai dengan persamaan regresi:

$$
\mathrm{DPR}=\beta 0+\beta_{1} \mathrm{PROF}+\beta_{2} \mathrm{CFPS}+\beta_{3} \mathrm{TAX}+\beta_{4} \mathrm{CR}
$$$$
+\beta_{5} \mathrm{MTBV}+\beta_{6} \mathrm{D} / \mathrm{E}+\beta_{7} \mathrm{FS}+\beta_{8} \mathrm{LCS}+\varepsilon
$$

Keterangan:

Y : Dividend Payout Ratio

BO : Konstanta

$\beta_{1}-\beta_{8}:$ : Koefisien regresi setiap variabel independen

PROF : Profitabilitas perusahaan i pada tahun $\mathrm{t}$

CFPS : Operating cash flow per share i pada tahun $\mathrm{t}$

TAX : Corporate tax perusahaan i pada tahun $\mathrm{t}$

CR : Current ratio perusahaan i pada tahun $t$

MTBV : Market to book value perusahaan i pada tahun $\mathrm{t}$

D/E : Debt to equity ratio perusahaan i pada tahun $t$

FS : Ukuran perusahaan i pada tahun $\mathrm{t}$

LCS : Life cycle stage perusahaan i pada tahun $\mathrm{t}$

$\varepsilon \quad$ : Nilai error atau kesalahan pengganggu

\section{HASIL PENELITIAN}

Berdasarkan laporan keuangan yang diperoleh dari Bursa Efek Indonesia selama tahun 2012 sampai dengan tahun 2014 terdapat 326 data perusahaan yang digunakan dalam penelitian. Hasil pengolahan statistik deskriptif variabel-variabel yang digunakan dapat dilihat pada tabel di bawah ini: 
Tabel 2 Statistik Deskriptif

\begin{tabular}{|lrrrrr|}
\hline Variabel & $\mathbf{n}$ & Minimum & Maksimum & \multicolumn{1}{c|}{ Mean } & Std.Deviation \\
\hline DPR & 326 & 0,0161 & 1,3273 & 0,327144 & 0,1991358 \\
PROF & 326 & 0,0248 & 2,6739 & 0,152994 & 0,1705996 \\
CFPS & 326 & $-4559,2875$ & 21776,5628 & 633,600396 & 2384,542322 \\
TAX & 326 & 0,0000 & 1,0324 & 0,247460 & 0,0995866 \\
CR & 326 & 0,3896 & 12,2281 & 2,423591 & 1,7852680 \\
MTBV & 326 & 0,2246 & 53,5901 & 3,256425 & 5,0463632 \\
DE & 326 & 0,0751 & 5,6661 & 1,062108 & 1,0169238 \\
FS & 326 & 25,5796 & 33,0950 & 28,987897 & 1,5310922 \\
LCS & 326 & 0,0448 & 1,0718 & 0,583563 & 0,2466285 \\
\hline
\end{tabular}

Tabel 3

Hasil Uji Regresi Berganda

\begin{tabular}{lcc}
\hline \multicolumn{1}{c}{ Variabel } & B & Sig. \\
\hline (Constant) & $-0,285$ & 0,136 \\
PROF & 0,201 & 0,001 \\
CFPS & 0,000024 & 0,000 \\
TAX & 0,333 & 0,001 \\
CR & 0,004 & 0,562 \\
MTBV & 0,007 & 0,002 \\
DE & $-0,026$ & 0,019 \\
FS & 0,014 & 0,025 \\
LCS & 0,108 & 0,010 \\
\hline
\end{tabular}

Sumber: Hasil Pengolahan Data SPSS

Berdasarkan dari hasil pengujian yang ditunjukkan pada tabel 3 dapat diketahui bahwa untuk variabel profitabilitas (PROF) menunjukkan nilai sig. sebesar 0,001 lebih kecil dari 0,05 sehingga dapat disimpulkan bahwa hipotesis pertama $\left(\mathrm{H}_{1}\right)$ diterima. $\mathrm{Hal}$ ini menunjukkan bahwa variabel profitabilitas berpengaruh terhadap dividend payout ratio pada perusahaan non keuangan di Bursa Efek Indonesia. Dengan nilai koefisien korelasi sebesar 0,201 sehingga profitabilitas berpengaruh positif terhadap dividend payout ratio, semakin tinggi profitabilitas perusahaan maka dividen yang dibagikan juga akan meningkat.

Berdasarkan dari hasil pengujian yang ditunjukkan pada tabel 3 dapat diketahui bahwa untuk variabel operating cash flow per share (CFPS) menunjukkan nilai sig. sebesar 0,000 lebih kecil dari 0,05 sehingga dapat disimpulkan bahwa hipotesis kedua $\left(\mathrm{H}_{2}\right)$ diterima. Hal ini menunjukkan bahwa variabel operating cash flow per shareberpengaruh terhadap dividend payout ratio pada perusahaan non keuangan di Bursa Efek Indonesia. Dengan nilai koefisien korelasi sebesar 0,000024 sehingga operating cash flow per share berpengaruh positif terhadap dividend payout ratio, maka semakin tinggi dan meningkatnya arus kas suatu perusahaan akan mengakibatkan perusahaan membayar dividen dalam jumlah besar

Berdasarkan dari hasil pengujian yang ditunjukkan pada tabel 3 dapat diketahui bahwa untuk variable corporate tax (TAX) menunjukkan nilai sig. 0,001 lebih kecil dari 0,05 sehingga dapat disimpulkan bahwa hipotesis ketiga $\left(\mathrm{H}_{3}\right)$ diterima. Hal ini menunjukkan bahwa variabel 
corporate tax berpengaruh terhadap dividend payout ratio pada perusahaan non keuangan di Bursa Efek Indonesia. Dengan nilai koefisien korelasi sebesar 0,333 sehingga corporate tax berpengaruh positif terhadap dividend payout ratio, maka semakin tinggi nilai corporate tax suatu perusahaan maka akan meningkatkan besarnya dividen yang akan dibagikan.

Berdasarkan dari hasil pengujian yang ditunjukkan pada tabel 3 dapat diketahui bahwa untuk variabel current ratio (CR) menunjukkan nilai sig. 0,562 lebih besar dari 0,05 sehingga dapat disimpulkan bahwa hipotesis keempat $\left(\mathrm{H}_{4}\right)$ tidak dapat diterima. Hal ini menunjukkan bahwa variabel current ratio tidak berpengaruh terhadap dividend payout ratio pada perusahaan non keuangan di Bursa Efek Indonesia.

Berdasarkan dari hasil pengujian yang ditunjukkan pada tabel 3 dapat diketahui bahwa untuk variabel market to book value (MTBV) menunjukkan nilai sig. sebesar 0,002 lebih kecil dari 0,05 sehingga dapat disimpulkan bahwa hipotesis kelima $\left(\mathrm{H}_{5}\right)$ diterima. Hal ini menunjukkan bahwa variabel market to book value berpengaruh terhadap dividend payout ratio pada perusahaan non keuangan di Bursa Efek Indonesia. Dengan nilai koefisien korelasi sebesar 0,007 sehingga market to book value berpengaruh positif terhadap dividend payout ratio, maka semakin tinggi rasio market to book value perusahaan maka akan meningkatkan besarnya dividen yang dibagikan.

Berdasarkan dari hasil pengujian yang ditunjukkan pada tabel 4.10 dapat diketahui bahwa untuk variable debt to equity ratio (DE) menunjukkan nilai sig. 0,019 lebih kecil dari 0,05 sehingga dapat disimpulkan bahwa hipotesis alternatif keenam ( $\left.\mathrm{Ha}_{6}\right)$ diterima. $\mathrm{Hal}$ ini menunjukkan bahwa variabel debt to equity ratio berpengaruh terhadap dividend payout ratio pada perusahaan non keuangan di Bursa Efek Indonesia. Dengan nilai koefisien korelasi sebesar $-0,026$ sehingga debt to equity ratio berpengaruh negatif terhadap dividend payout ratio, maka semakin tinggi rasio debt to equity ratio pada suatu perusahaan maka akan menurunkan besarnya dividen yang dibagikan.

Berdasarkan dari hasil pengujian yang ditunjukkan pada tabel 3 dapat diketahui bahwa untuk variabel ukuran perusahaan (FS) menunjukkan nilai sig. sebesar 0,025 lebih kecil dari 0,05 sehingga dapat disimpulkan bahwa hipotesis ketujuh $\left(\mathrm{H}_{7}\right)$ diterima. $\mathrm{Hal}$ ini menunjukkan bahwa variabel ukuran perusahaan berpengaruh terhadap dividend payout ratio pada perusahaan non keuangan di Bursa Efek Indonesia. Dengan nilai koefisien korelasi sebesar 0,014 sehingga ukuran perusahaan berpengaruh positif terhadap dividend payout ratio, maka semakin tinggi rasio ukuran perusahaan pada suatu perusahaan maka akan meningkatkan besarnya dividen yang dibagikan.

Berdasarkan dari hasil pengujian yang ditunjukkan pada tabel 3 dapat diketahui bahwa untuk variabel life cycle stage (LCS) menunjukkan nilai sig. sebesar 0,010 lebih kecil dari 0,05 sehingga dapat disimpulkan bahwa hipotesis kedelapan $\left(\mathrm{H}_{8}\right)$ diterima. Hasil ini menunjukkan bahwa variabel life cycle stage berpengaruh terhadap dividend payout ratio pada perusahaan non keuangan yang terdaftar di Bursa Efek Indonesia. Dengan memiliki nilai koefisien korelasi sebesar 0,108 sehingga life cycle stage dapat dinyatakan berpengaruh positif terhadap dividend payout ratio, maka semakin tinggi rasio life cycle stage pada suatu perusahaan maka akan meningkatkan besarnya dividen yang akan dibagikan.

\section{PENUTUP}

Berdasarkan pengujian hipotesis yang telah dilakukan, dapat diambil kesimpulan sebagai berikut: 1) Profitabilitas berpengaruh terhadap dividend payout ratio; 2) Operating Cash Flow berpengaruh terhadap dividend payout ratio; 3) Corporate Tax berpengaruh terhadap dividend payout ratio; 4) Curent Ratio tidak berpengaruh terhadap dividend payout 
ratio; 5) Market to Book Value berpengaruh terhadap dividend payout ratio; 6) Debt to Equity Ratio berpengaruh terhadap dividend payout ratio; 7) Ukuran Perusahaan berpengaruh terhadap dividend payout ratio; 8) Life Cycle Stage berpengaruh terhadap dividend payout ratio.

Penelitian ini memiliki beberapa keterbatasan yang dapat menjadi masukan bagi penelitian selanjutnya. Keterbatasan dalam penelitian ini antara lain: 1) Periode penelitian yang diambil oleh penulis hanya tiga tahun, yaitu dari tahun 2012 sampai 2014 dimana dapat dikatakan masih relatif pendek; 2) Penelitian ini hanya menggunakan 8 variabel independen, yaitu profitabilitas, operating cash flow per share, corporate tax, current ratio, market to book value, debt to equity ratio, ukuran perusahaan, dan life cycle stage; 3) Data dalam penelitian ini masih mengalami masalah dalam uji asumsi klasik, yaitu terjadinya heteroskedastisitas yang terdapat pada variabel market to book value.

Berdasarkan keterbatasan yang ada, rekomendasi atau saran yang dapat diberikan untuk penelitian selanjutnya antara lain: 1) Peneliti selanjutnya diharapkan dapat menambah periode penelitian menjadi lima tahun atau lebih sehingga sampel yang digunakan lebih banyak dan data yang dihasilkan lebih akurat; 2) Peneliti selanjutnya dianjurkan untuk dapat menambah variabelvariabel independen lainnya yang juga dapat mempengaruhi dividend payout ratio, seperti: growth, net profit margin, struktur kepemilikan, umur perusahaan, dan sebagainya; 3) Peneliti selanjutnya diharapkan dapat menghasilkan data yang terhindar dari masalah heterokedasitas yaitu dengan melakukan transformasi data atau dengan menambah jumlah data yang diteliti.

\section{REFERENSI:}

Ano, Rizki Rurniawan., Sri Murni, dan Paulina Van Rate. 2014. Pengaruh Likuiditas dan Profitabilitias terhadap Dividend Payout Ratio pada Sub sektor Perbankan yang Terdaftar di Bursa Efek Indonesia.Jurnal EMBA, Vol.2 No. 3: 884-894.

Bansaleng, Resky D.V., Parengkuan Tommy, dan Ivonne S. Saerang. 2014. Kebijakan Hutang, Struktur Kepemilikan, dan Profitabilitas terhadap Kebijakan Dividen pada Perusahaan Food and Beverage di Bursa Efek Indonesia. Jurnal EMBA, Vol. 2 No. 3: 817-830.

Beams, Floyd A., Joseph H. Anthony, Bruce Bettinghaus, dan Kenneth A. Smith. 2012. Advanced Accounting 11th edition. Pearson.

Damayanti, Yustiara Ismi., dan Catur Rahayu Martiningtiyas. 2014. Faktor-Faktor yang Mempengaruhi Kebijakan Pembayaran Dividen. e-Journal Manajemen, Vol. 1 No. 2:70-83.

DeAngelo, Harry., Linda DeAngelo, dan Rene M Stulz. 2006. Dividend Policy and The Earned/Contributed Capital Mix: A Test of the Life Cycle Theory. Journal of Financial Economics, Vol. 81: 227-254

Demergunes, Kartal. 2015. Determinants of Target Dividend Payout Ratio: A Panel Autoregressive Distributed Lag Analysis. International Journal of Economics and Financial Issues, Vol. 5 No. 2

Dhira, Nindi Septia One., Novi Wulandari, dan Nining Ika Wahyuni. 2014. Pengaruh Laba Bersih, Arus Kas Operasi dan Ukuran Perusahaan terhadap Kebijakan Dividen (Studi Empiris pada Perusahaan Manufaktur yang Listed di Bursa Efek Indonesia). Jurnal Ekonomi, Akuntansi, dan Manajemen Fakultas Ekonomi Universitas Jember. 
Fama, Eugene F., dan Kenneth R. French. 2001. Disappearing Dividends: Changing Firm Characteristic or Lower Propensity to Pay. Journal of Financial Economic, Vol. 61: 3-43

Ghozali, Imam. 2013. Aplikasi Analisis Multivariate dengan Program IBM SPSS 21 Cetakan VII. Semarang: Badan Penerbit Universitas Diponegoro.

Gitman, Lawrence J., dan Chad J. Zutter. 2015. Principles of Managerial Finance 14th edition. Prentice Hall.

Kieso., Donald E., Jerry Weygandt, dan Terry D. Warfield. 2011. Intermediate Accounting IFRS Edition. John Wiley \& Sons Inc.

Kristanto, Haris., dan Sumani. 2015. Pengaruh Perubahan Arus Kas Operasi, Laba Akuntansi, Suku Bunga, Dan Inflasi Terhadap Return Saham. Banking and Management Review, Vol. 4 No. 2.

Mahaputra, Gede Agus., dan Ni Gusti Putu Wirawati. 2014. Pengaruh Faktor Keuangan dan Ukuran Perusahaan pada Dividend Payout Ratio Perusahaan Perbankan. e-Jurnal Akuntansi, Vol. 3 No. 9: 695-708.

Mahesti, Febrijani Sri., Theresia Purbandari, dan Mujilan. 2013. Faktor-faktor yang mempengaruhi Dividend Payout Ratio pada Perusahaan Manufaktur yang Terdaftar di BEl Tahun 2009-2011.Jurnal Riset Manajemen dan Akuntansi, Vol. 1 No. 2:13-21.

Maladjian, Christopher., dan Rim El Khoury. 2014. Determinants of the Dividend Policy: An Empirical Study on the Labanese Listed Banks. International Journal of Economics and Finance, Vol.6 No.4.

Marietta, Unzu., dan Djoko Sampurno.2013. Analisis Pengaruh Cash Ratio, Return on Assets, Growth, Firm Size, Debt to Equity Ratio terhadap Dividend Payout Ratio: (Studi pada Perusahaan Manufaktur yang Terdaftar di Bursa Efek Indonesia tahun 2008-2011). Diponogoro Journal of Management, Vol. 2 No.3: 1-11.

Mawarni, Luh Fajarini Indah., dan Ni Made Dwi Ratnadi. 2014. Pengaruh Kesempatan Investasi, Leverage dan Likuiditas pada Kebijakan Dividen Perusahaan Manufaktur yang Terdaftar di BEI. e-Jurnal Akuntansi Universitas Udayana, Vol. 9 No. 1: 200-208.

Myers, Stewart C., dan Nicholas S. Majluf. 1984. Corporate Financing and Investment Decisions When Firms Have Information That Investor Do Not Have.Journal of Financial Economics, Vol.13: 187-221.

Parsian, Hosein., dan Shams Koloukhi. 2014. A Study on The Effect of Free Cash Flow and Profitability Current Ratio on Dividend Payout Ratio: Evidence from Tehran Stock Exchange. Management Science Letters, Vol. 4: 63-70.

Pramana, Gede Rian Aditya., dan I Made Sukartha. 2015. Analisis Faktor-faktor yang Mempengaruhi Kebijakan Dividen di Bursa Efek Indonesia. E-Jurnal Akuntansi Univesitas Udayana, Vol.12 No.2: 221-232.

Prasetyo, Fayakun Nur., dan R. Djoko Sampurno. 2013. Analisis Net Profit Margin, Current Ratio, Debt to Equity Ratio, Company's Growth, Firm Size, dan Collateralizable Assets terhadap Dividend Payout Ratio. Diponogoro Journal of Management, Vol. 2 No. 2: 1-12.

Purnami, Kadek Diah Arie., dan Luh Gede Sri Artini. 2016. Pengaruh Investment Opportunity Set, Total Asset Turn Over dan Sales Growth terhadap Kebijakan Dividen. E-Jurnal Manajemen Unud, Vol. 5 No. 2.

Rafique, Mahira. 2012. Factor Affecting Dividend Payout: Evidence From Listed Non-Financial Firms of Karachi Stock Exchange. Business Management Dynamic, Vol. 1 No. 11.

Refra, Erviliana., dan Maria C. Widiastuti. 2014. Pengaruh Profitability, Firm Size, Tax, Investment Opportunities, Life Cycle Stage terhadap Dividend Policy pada Industri Manufaktur di Indonesia. E-Journal Manajemen Fakultas Ekonomi Universitas Trisakti, Vol. 1 No. 2: 84-105.

Rehman, Abdul., dan Haruto Takumi. 2012. Determinants of Dividend Payout Ratio: Evidence From Karachi Stock Exchange (KSE). Journal of Contemporary Issues in Business Research, Vol. 1 No. 1: 20-27.

Samrotun, Yuli Chromsatu. 2015. Kebijakan Dividen dan Faktor-faktor yang mempengaruhinya. Jurnal Paradigma, Vol. 13 No. 1: 92-103.

Saeed, Dr. Rashid., Ayesha Riaz, Rab Nawas Lodhi, Hafiza Mubeen Munir, dan Amber Iqbal. 2014. Determinant of Dividend Payout in Financial Sector of Pakistan. Journal of Basic and Applied Scientific Research. Vol. 4 No. 2: 33-42 
Sanjari, Tahere., dan Batool Zarei. 2014. The Study Factors Influencing Corporate Dividend Policy of Financial and Non-Financial Firms on Companies Listed in Tehran Stock Exchange. Research Journal of Finance and Accounting. Vol. 5 No. 21: 138-144

Santoso, Singgih. 2012. Aplikasi SPSS pada statistik non parametric. Jakarta: PT Elex Media Komputindo.

Sekaran, Uma.,dan Roger Bougie. 2013. Research Method For Business, $6^{\text {Th }}$ Edition, John Wiley \& Sons Ltd.

Siswantini, Wiwin. 2014. Pengaruh Analisis Rasio Keuangan terhadap Kebijakan Dividen. Jurnal Derivatif Manajemen, Vol. 8 No. 2: 1-19.

Sjahrial, Prof. Dr. Dermawan MM. 2010. Manajemen Keuangan Edisi 4. Jakarta: Penerbit Mitra Wacana Media.

Suliyanto.2011. Ekonometrika Terapan-Teori dan Aplikasi dengan SPSS. Yogyakarta: ANDI.

Suprihati. 2015. PengaruhCash Ratio, Debt To Equity Ratio, Market To Book Value Ratio, Institutional Ownership dan Return On Asset terhadap Dividend Payout Ratio Pada Perusahaan yang termasuk Tertiary Sectors Di Bursa Efek Indonesia. Jurnal Paradigma, Vol. 12 No. 2: 227-254.

Tampubolon, Prof. Dr. Manahan P. 2005. Manajemen Keuangan (Finance Management) Konseptual, Problem, dan Studi Kasus. Bogor: Ghalia Indonesia.

Thanatawee, Yordying. 2013. Ownership Structure and Dividend Policy: Evidence From Thailand. International Journal Of Economics and Finance. Vol. 5 No.1: 121-132.

Weston, J. Fred. dan Brigham Eugene F., terjemahan. 1986. Dasar-dasar Manajemen Keuangan. Jakarta: Penerbit Erlangga. 